Olena Voloshkina, Dr, Professor of the Department of Labour and Environment Protection ORCID ID 0000-0002-3671-4449 e-mail: e.voloshki@gmail.com

Olena Zhukova, PhD, Associate Professor of the Department of Labour and Environment Protection

ORCID ID 0000-0003-0662-9996 e-mail: elenazykova21@gmail.com

Irina Korduba, $\mathrm{PhD}$, Associate Professor of the Department of Labour and Environment Protection

$\boldsymbol{e}$-mail: uaror-korduba@ukr.net

Daniil Marshall, graduate student of the Department of Labour and Environment Protection e-mail: daniil.marshall@icloud.com

Kyiv National University of Construction and Architecture, Kyiv, Ukraine

\title{
METHODICAL APPROACHES TO THE EVALUATION OF SURFACE POLLUTION OF WATER OBJECTS IN THE AREA OF MINING ENTERPRISES (ON THE EXAMPLE OF DONETSK-PRIDNIPROVSK REGION)
}

\begin{abstract}
The most important component of ecologically safe development of natural and socio-economic systems is the use of nature, which involves the organization of water resources, which ensures sustainable development and for a long time retains sufficient water potential. The XXI century is characterized by significant negative changes in the natural environment caused by the uncontrolled use of natural resources, the development of industry and transport, which leads to increased water consumption and at the same time increase its pollution. This has been particularly noticeable over the last 50 years, when human impact on the planet's water cycle has reached a global scale. Deterioration of the ecological condition of surface waters is due to qualitative and quantitative depletion of factors of their formation, which in some cases makes it impossible to use them for economic purposes. Water quality of water bodies is formed under the influence of both natural and anthropogenic factors. As a result of human activity in reservoirs many anthropogenic substances of various degree of toxicity can arrive. The article attempts to assess changes in surface water quality over the past decade and to determine the degree of natural and man-made transformation of rivers in the region and the possibility of their self-restoration and stabilization of the ecological danger of the region. The existing methods of assessment of water bodies by chemical indicators used in the area of operation of mining enterprises are considered. In some methods, the assessment of water bodies usually reflects regional features rather than their own pollution. Calculations for the water basin river Siverskyi Donets are made and relevant patterns are established.
\end{abstract}

Key words: pollution; surface water bodies; anthropogenic impact; quality index; self-healing

О.С. Волошкіна, О.Г. Жукова, І.Б. Кордуба, Д.І. Маршалл, 2021 


\title{
О.С. Волошкіна, О.Г. Жукова, І.Б. Кордуба, Д.І. Маршалл
}

Київський національний університет будівництва та архітектури, м. Київ, Україна

\section{МЕТОДИЧНІ ПІДХОДИ ДО ОЦІНКИ ЗАБРУДНЕННЯ ПОВЕРХНЕВИХ ВОДНИХ ОБ'СКТІВ В ЗОНІ ДІЇ ГІРНИЧО- ВИДОБУВНИХ ПІДПРИЕМСТВ (НА ПРИКЛАДІ ДОНЕЦЬКО- ПРИДНІПРОВСЬКОГО РЕГІОНУ)}

\begin{abstract}
Анотація. Найважливішою складовою екологічно безпечного розвитку природних і сочіально-економічних систем є таке природокористування, яке передбачає організацію використання водних ресурсів, при якому забезпечується сталий розвиток і протягом тривалого часу зберігається для иъього достатній водно-ресурсний потенціал. ХХІ століття характеризується значними негативними змінами природного середовища, викликаними безконтрольним використанням природних ресурсів, розвитком промисловості та транспорту, що призводить до збільшення споживання води $і$ водночас зростання ї̈ забруднення. Особливо ие стало помітним протягом останніх 50 років, коли вплив людини на водний цикл планети досягнув глобального масштабу. Погіршення екологічного стану поверхневих вод суходолу зумовлено якісним та кількісним виснаженням факторів їх формування, що у низиі випадків унеможливлює їх використання для господарських иілей. Якість вод водних об'єктів формується під впливом як природних, так і антропогенних факторів. В результаті людської діяльності у водойми може надходити багато антропогенних речовин різного ступеня токсичності. В статті зроблена спроба оцінити зміни якості поверхневих вод за останне десятиліття та визначити ступінь природно-техногенної трансформачії річок регіону та можливість їх самовідновлення та стабілізації стану екологічної небезпеки регіону. Розглянуті існуючі методи оцінки водних об'єктів за хімічними показниками, які використовують в зоні дії гірничо-видобувних підприємств. В низиі методів очінка водних об'єктів зазвичай відображає регіональні особливості, а не власне їх забруднення. Проведені розрахунки для водного басейну $p$. Сіверський Донець та встановлені відповідні закономірності.
\end{abstract}

Ключові слова: забруднення; поверхневі водні об'єкти; антропогенний вплив; індекс якості; самовідновлення

DOI: https://doi.org/10.32347/2411-4049.2021.3.69-75

\section{Вступ}

Якість вод водних об'єктів формується під впливом як природних, так i антропогенних факторів. В результаті людської діяльності у водойми може надходити багато антропогенних речовин різного ступеня токсичності. Забруднюють водойми стоки сільськогосподарських i промислових підприємств, стічні води населених пунктів. У сучасних умовах проблема забезпечення населення чистою водою стає все більш актуальною, а дослідження стану водних об'єктів є одним з найважливіших завдань.

Що стосується розглядуваного регіону, то левова частина забруднень, які надходять в поверхневі води, міститься в стічних водах промислових підприємств. Так, станом на 2018 рік у Донецькій області на підконтрольній території працювало 17 потенційно небезпечних підприємств, в Луганській області - 10 (на непідконтрольній 5 і 15 - відповідно). Також причиною 
погіршення якості є неконтрольоване закриття нерентабельних шахт регіону (як на підконтрольній, так i на непідконтрольній території), що мають гідравлічний взаємозв'язок. Про цей вплив свідчить насамперед поступове підвищення показників мінералізації в басейнах річок ДонецькоПридніпровського регіону, особливо активно починаючи 32000 року. Наприклад, за даними Національної доповіді за 2018 рік, показник загальної мінералізації в поверхневих водах р. Самара сягнув 2800 мг/л.

\section{Результати досліджень}

В даному дослідженні зроблена спроба оцінити зміни якості поверхневих вод за останне десятиліття та визначити ступінь природно-техногенної трансформації річок регіону та можливість їх самовідновлення та стабілізації стану екологічної небезпеки регіону.

На даний час маємо численні дослідження щодо розроблення або удосконалення існуючих методів оцінки якості.

Незважаючи на тривалий період активних розробок в цій області (близько 40 років), більшість проблемних питань і сьогодні знаходяться в стадії дослідження. Рівень і якість їх вивченості неоднакові; істотно відрізняється ступінь теоретичної розробки окремих елементів процедури оцінювання.

Алгоритм отримання інтегральних індексів складається з реєстру вихідних показників хімічного складу води і методик їх визначення, вибору стандарту для екологічної градації якості води за кожним показником, методу розрахунку індексу і еталонів для інтегральної оцінки води.

На сьогодні основна частина запропонованих методів оцінки забруднення поверхневих гідроекосистем грунтується на ГДК. Умовно ці методи можна поділити на дві групи:

- ті, які дозволяють оцінити якість води за сукупністю хімічних, біологічних, мікробіологічних та фізичних показників;

- ті, які пов'язані з розрахунком комплексних індексів забруднення води.

Прикладом першої групи методів є класифікація, в якій водні об'єкти діляться на класи за хімічними, бактеріологічними та біологічними показниками. Відповідно якість води оцінюється за іiі фізичними та органолептичними властивостями. В якості найвагоміших показників рекомендується використання наступних показників: титр кишкової палички, запах, БСК 5 , азот амонійний, наявність нафтопродуктів та ін. Із комплексних індексів на основі ГДК найбільш популярними $є$ IЗВ.

В досліджуваному нами регіоні розташовані водний басейн Сіверського Дінця та річок Приазов'я. Донецько-Придніпровський регіон займає близько $19 \%$ території України. Тут розташовані майже 5 тисяч підприємств металургійної, хімічної, енергетичної, машинобудівної, гірничої, вугільної та інших галузей.

В досліджуваному регіоні можна виділити декілька типів техногенних вод:

- рудні води, які накопичуються в кар'єрах та шахтах;

- води, які фільтруються з відвалів відкритих порід;

- води хвостосховищ;

- фільтраційні води, які утворюються внаслідок фільтрації води. 
Необхідно відмітити деякі особливості техногенних вод:

- вони характеризуються високим ступенем мінералізації, що не характерно для природних вод. Такі аномалії суттєво впливають на життєдіяльність гідробіонтів та якість питного водопостачання;

- води характеризуються високим нерівномірним вмістом азотомістких речовин;

- висока варіабельність вмісту мікроелементів.

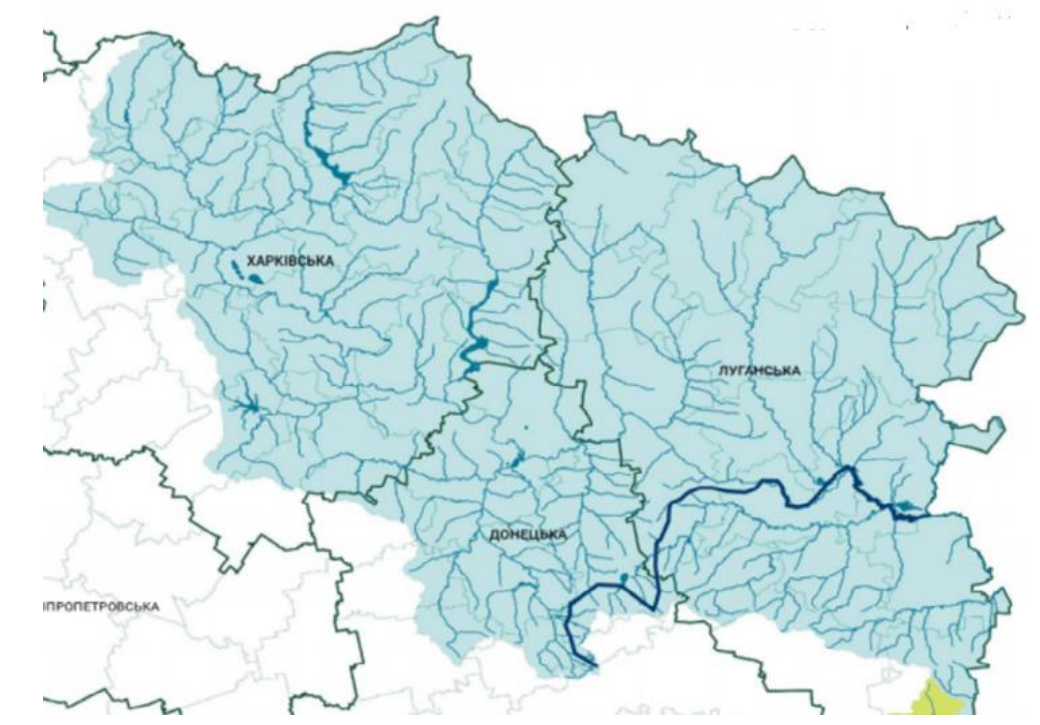

Рис. 1 - Карта-схема району дослідження басейну р. Сіверського Дінця 3 лінією розмежування на підконтрольній та непідконтрольній території (за матеріалами місії ОБСС)

Оцінити стан техногенного забруднення водних екосистем в повній мірі немає можливості, що пов'язано з відсутністю регулярних відборів проб та проведенням АТО. За останніми дослідженнями всі гідроекосистеми відносяться до брудних. Оцінка за БСК цілком зрозуміла, оскільки води забруднені мінеральними речовинами і це відображається на величині БСК.

За досліджуваний період поверхневі води у створах вздовж водотоку річки Сіверський Донець на основі Інтегрального показника якості води (категорія) відносяться переважно до III класу якості 4 категорії (задовільні, слабко забруднені). Найбільш забрудненими притоками на основі Інтегрального показника якості води (категорія) є річки Казенний Торець і Бахмутка, які відповідають III класу якості 5 категорії (посередні, помірно забруднені).

Концентрації сольових показників, біогенних, органічних, специфічних речовин незначно коливаються на рівні минулого року та середньобагаторічних показників. Відзначається перевищення середньорічних ГДК по: БСК 1,5-2,2 ГДК, азоту амонійному - до 2,8 ГДК, залізу загальному - до 2,2 ГДК, марганцю - 2,8-11,3 ГДК, міді - 2,5-4,3 ГДК, нафтопродуктам - до 2,4 ГДК, нітритам - до 5,2 ГДК, хрому (VI) - 3,8-7,5 ГДК, цинку - 1,3-2,6 ГДК. Кисневий режим задовільний. Вміст токсикологічних інгредієнтів у створах по руслу р. Сіверський Донець нижчий за межу визначення методик, у створах суббасейнів - значно нижчий встановлених ГДК. 
Таблиця 1 - Усереднені показники техногенного забруднення основних гідроекосистем

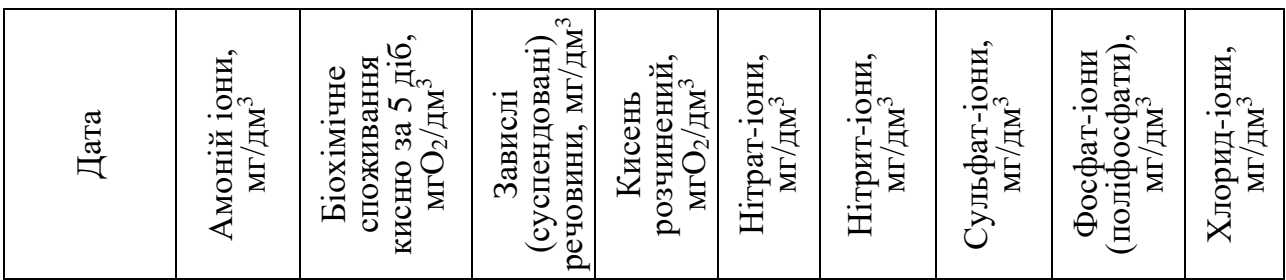

p. Сіверський Донець, 522 км, м. Слов'янськ, Райгородська гребля, питний водозабір у канал "Сіверський Донець - Донбас"

\begin{tabular}{|l|l|c|c|c|c|c|c|c|c|}
\hline 13.01 .20 & 2,090 & 3,600 & 9,000 & 9,82 & 7,430 & 0,076 & 278,6 & 1,200 & 71,0 \\
\hline 11.02 .20 & 2,210 & 3,580 & 9,500 & 10,05 & 7,880 & 0,080 & 269,0 & 1,220 & 78,1 \\
\hline 04.03 .20 & 2,230 & 3,580 & 9,000 & 10,20 & 7,920 & 0,078 & 269,0 & 1,160 & 71,0 \\
\hline 06.04 .20 & 1,990 & 3,560 & 9,500 & 10,05 & 7,150 & 0,070 & 269,0 & 1,100 & 67,4 \\
\hline 05.05 .20 & 2,110 & 3,600 & 9,200 & 9,87 & 7,600 & 0,074 & 288,2 & 1,180 & 71,0 \\
\hline 03.06 .20 & 2,190 & 3,620 & 9,400 & 9,78 & 7,880 & 0,080 & 278,6 & 1,200 & 71,0 \\
\hline 20.07 .20 & 1,900 & 3,580 & 11,000 & 9,27 & 6,510 & 0,085 & 288,2 & 1,640 & 71,0 \\
\hline 11.08 .20 & 2,200 & 3,520 & 10,800 & 8,94 & 7,130 & 0,082 & 278,6 & 1,620 & 71,0 \\
\hline 03.09 .20 & 1,980 & 3,580 & 11,000 & 7,96 & 7,880 & 0,078 & 288,2 & 1,220 & 63,9 \\
\hline
\end{tabular}

Відповідно до даних таблиці 1 на прикладі одного створу спостерігається перевищення ГДК за досліджуваними показниками. Дані по таблиці отримані в Державному агентстві водних ресурсів України. По інших створах спостереження відзначається подібна ситуація.

Про зростаюче ускладнення водно-екологічних умов ПГВ регіону Донбасу може свідчити також стійке погіршення санітарно-хімічних показників проб води. Так, в пробах, відібраних за період 2010-2012 рр. як у містах і селищах, так і сільських населених пунктах, відповідно:

- по Донецькій області - збільшення від 39,7 до 49,8\% та від 17,7 до 17,9\%;

- по Луганській області - збільшення від 56,8 до 59,5\% та від 86,7 до 88\%.

Таблиця 2 - Усереднені результати обчислення екологічних показників стану водного басейну р. Сіверський Донець

\begin{tabular}{|c|c|c|c|c|c|c|}
\hline \multirow[b]{2}{*}{$\begin{array}{c}\text { Період } \\
\text { дослідження }\end{array}$} & \multirow[b]{2}{*}{ I3B } & \multirow[b]{2}{*}{$\mathrm{I}_{\mathrm{e}}$} & \multicolumn{3}{|c|}{$\begin{array}{c}\text { Коефіцієнт } \\
\text { самовідновної } \\
\text { здатності, \% випадків }\end{array}$} & \multirow[b]{2}{*}{$\begin{array}{c}\text { Індекс } \\
\text { сапробності }\end{array}$} \\
\hline & & & 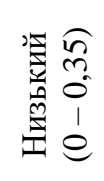 & 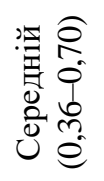 & 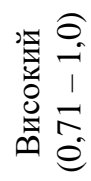 & \\
\hline $1990-2000$ & 2,3 (III-забруднена) & 4,11 & 65,23 & 33,1 & 1,67 & 0,43 \\
\hline $2001-2010$ & 2,25 (III-забруднена) & 3,56 & 71,56 & 27,64 & 0,8 & 0,29 \\
\hline $2011-2020$ & 2,03 (III-забруднена) & 3,15 & 81,47 & 17,97 & 0,56 & 0,35 \\
\hline
\end{tabular}

Підтвердженням стійкого забруднення поверхневих джерел ПГВ та їх водозборів $є$ довгострокове виявлення у пробах колі-фагів, вміст яких до десятків разів перевищує припустимі рівні (Донецька обласна СЕС, епізодичні дані 2000-2013 pp.). 
Аналізуючи показники наявного моніторингу в 2020 році та порівнюючи їх iз даними періодичного моніторингу, зроблено висновок про суттєве погіршення якості води майже за всіма якісними та кількісними показниками водних екосистем.

Проведене дослідження механізму здатності водних об'єктів до самовідновлення по ряду існуючих створів спостережень свідчить про значну часткову втрату цієї складової у водних екосистемах за останні 10 років (порівняно з 1990-2010 рр.).

\section{Висновки}

У зв'язку з вищенаведеним можна зробити наступні висновки:

1. Аналіз сучасної водно-екологічної ситуації досліджуваної території свідчить про суттєве погіршення якості та часткову втрату властивостей самоочищення на прикладі окремих даних спостережень та на окремих створах.

2. Ці обставини зумовлюють необхідність постійного гідрохімічного контролю поверхневих вод та джерел резервного водопостачання в зонах впливу потенційно небезпечних підприємств, а також в зонах впливу затоплення шахт для забезпечення підтримки регіонального екологічного управління та запобігання виникненню надзвичайних ситуацій водноекологічного походження.

\section{СПИСОК ЛІТЕРАТУРИ}

1. Былинкина А.А., Драчев С.М., Ицкова А.И. О приемах графического изображения аналитических данных о состоянии водоемов // Матер. 16-го гидрохим. совещ. Новочеркасск, 1962. С. 8-15.

2. Гагарина О.В. Обзор методов комплексной оценки качества поверхностных вод // Науки о Земле. 2005. № 11. С. 45-58.

3. Жукинский В.Н., Оксиюк О.П., Олейник Г.Н., Кошелева С.И. Критерии комплексной оценки качества поверхностных пресных вод // Самоочищение и биоиндикация загрязненных вод. М.: Наука, 1980. С. 57-63.

4. Замолодчиков Д.Г. Оценка экологически допустимых уровней антропогенного воздействия на пресноводные экосистемы // Проблемы экологического мониторинга и моделирования экосистем. Т. XV. СПб.: Гидрометеоиздат, 1993. С. 214-233.

5. Основы экогеологии, биоиндикации и биотестирования водных экосистем / Под ред. Куриленко В.В. СПб.: СПбГУ, 2004. 448 с.

6. Патин С.А. Влияние загрязнения на биологические ресурсы и продуктивность мирового океана. М.: Пищевая пром-ть, 1979. 304 с.

7. Удод В.М. Разработка современных биоценотических методов контроля экологического состояния гидроэкосистем рек / В.М. Удод, И.Л. Вильдман, Е.Г. Жукова // Восточно-Европейский журнал передовых технологий. - Харьков, 2014. - Вып. 5/10(71). - С. 4-11.

8. Кулинич Я.І. Зниження техногенного впливу притоки водного басейну Кальміус р. Кальчик за рахунок використання берегового біоплато / Я.І. Кулинич, О.Г. Жукова // Актуальні проблеми сучасної гідроекології: зб. мат. наук.-практ. конф., присвяченої 95-річчю заснування Національної академії наук України (5-6 листопада 2013 р.). Київ. - С. 55-56.

Стаття надійшла до редакиії 15.03.2021 і прийнята до друку після рецензування 17.06.2021 


\section{REFERENCES}

1. Bylinkina, A.A., Drachev, S.M., \& Itskova, A.I. (1962). On the methods of graphical representation of analytical data on the state of reservoirs. In Mater. 16th hydrochem. meeting (pp. 8-15). Novocherkassk [in Russian].

2. Gagarina, O.V. (2005). Review of methods for integrated assessment of surface water quality. Earth Sciences, 11, 45-58 [in Russian].

3. Zhukinsky, V.N., Oksiyuk, O.P., Oleynik, G.N., \& Kosheleva, S.I. (1980). Criteria for a comprehensive assessment of the quality of surface fresh water. In Self-purification and bioindication of contaminated water (pp. 57-63). Moscow: Nauka [in Russian].

4. Zamolodchikov, D.G. (1993). Estimation of ecologically admissible levels of anthropogenic impact on freshwater ecosystems. In Problems of ecological monitoring and modeling of ecosystems (Vol. XV, pp. 214-233). Sankt Peterburg: Gidrometeoizdat [in Russian].

5. Kurylenko, V.V.(Ed.). (2004). Fundamentals of ecogeology, bioindication and biotesting of aquatic ecosystems. Sankt Peterburg: SPbGU [in Russian].

6. Patin, S.A. (1979). Impact of pollution on biological resources and productivity of the world's oceans. Moscow: Pishchevaya prom-t [in Russian].

7. Udod, V.M., Wildman, I.L., \& Zhukova, E.G. (2014). Development of modern biocoenotic methods of control of ecological condition of river hydroecosystems. Eastern European Journal of Advanced Technologies, 5/10(71), 4-11 [in Russian].

8. Kulinich, Y.I., \& Zhukova, O.G. (2013). Reduction of technogenic impact of the inflow of the Kalmius river basin of the Kalchyk river due to the use of the coastal bioplateau. In Actual problems of modern hydroecology: collection. mate. scientific-practical conference dedicated to the 95th anniversary of the National Academy of Sciences of Ukraine (pp. 55-56). Kyiv [in Ukrainian].

The article was received 15.03.2021 and was accepted after revision 17.06.2021

\section{Волошкіна Олена Семенівна}

доктор технічних наук, професор кафедри охорони праці та навколишнього середовища Київського національного університету будівництва і архітектури

Адреса робоча: 03037, Україна, м. Київ, пр-т Повітрофлотський, 31

ORCID ID 0000-0002-3671-4449 e-mail: e.voloshki@gmail.com

\section{Жукова Олена Григорівна}

кандидат технічних наук, доцент кафедри охорони праці та навколишнього середовища Київського національного університету будівництва і архітектури

Адреса робоча: 03037, Україна, м. Київ, пр-т Повітрофлотський, 31

ORCID ID 0000-0003-0662-9996 e-mail: elenazykova21@gmail.com

\section{Кордуба Ірина Богданівна}

кандидат технічних наук, доцент кафедри охорони праці та навколишнього середовища Київського національного університету будівництва і архітектури

Адреса робоча: 03037, Україна, м. Київ, пр-т Повітрофлотський, 31

e-mail: uamrv_ibk@ukr.net

Маршалл Данііл Ігорович, аспірант кафедри охорони праці та навколишнього середовища Київського національного університету будівництва і архітектури

Адреса робоча: 03037, Україна, м. Київ, пр-т Повітрофлотський, 31

e-mail: daniil.marshall@icloud.com 